Gut, 1962, 3, 260

\title{
The role of seromucoid estimations in the investigation of haematemesis
}

\author{
EWAN CAMERON, ALLAN CAMPBELL, AND WILliAM PLENDERLEITH \\ From the Vale of Leven Hospital, Alexandria, Dunbartonshire, and the Royal \\ Alexandra Infirmary, Paisley, Renfrewshire
}

EDITORIAL SYNOPSIS This paper reports the role of seromucoid estimations in the diagnosis of upper gastrointestinal haemorrhage. Oesophageal varices, peptic ulcer, and carcinoma of the stomach tend to be divided by low, normal, and high levels respectively.

In Britain, peptic ulceration is the commonest cause of upper gastrointestinal haemorrhage. Although carcinoma of the stomach and ruptured oesophageal varices together account for only a small proportion of cases, early differentiation of the causal lesion is important from the point of view of treatment. As the seromucoid fraction of the serum polysaccharides is raised in cancer (Winzler and Smyth, 1948; Lockey, Anderson, and Maclagan, 1956; Cameron, Campbell, and Plenderleith, 1961a) and depressed in hepatocellular diseases (Greenspan, Lehman, Graff, and Schoenbach, 1951; Cameron et al., 1961b), it occurred to us that seromucoid estimation might be a useful screening test in patients admitted with haematemesis and melaena. In this communication we present the results of seromucoid estimations in 50 such patients, and discuss the diagnostic value of the procedure.

\section{METHOD}

Seromucoid was estimated by the original Winzler method with minor technical modifications as detailed in our previous communication (Cameron et al., 1961a). In a preliminary study of 60 healthy control subjects, we have found the normal value of seromucoid in our laboratory to be $3.5 \pm 0.75$ expressed as milligrams seromucoid tyrosine equivalent per $100 \mathrm{ml}$. serum $(\mathrm{mg}$. SMT/100 ml.).

\section{MATERIAL}

Seromucoid estimations were carried out on 50 patients admitted with major upper gastrointestinal haemorrhage. Blood samples for biochemical estimation were obtained soon after admission during the acute phase of the illness. The recorded diagnosis on each patient was the final diagnosis established on the basis of clinical, radiological, and biochemical observations, supported in some by endoscopic, operation, or necropsy findings. Twelve patients with essentially negative investigations and regarded as having bled from acute gastric erosions have been included within the 'peptic ulceration' group.

\section{RESULTS}

The seromucoid levels of the 50 patients admitted with major upper gastrointestinal haemorrhage are presented in Table I. It is apparent that the seromucoid levels of the patients who bled from oesophageal varices are significantly lower than the levels of the peptic ulcer group $(t=4.1 ; p<0.001)$. It is also apparent that the seromucoid levels of the patients in whom the source of the bleeding proved to be carcinoma of the stomach are significantly higher than the levels of the patients bleeding from peptic ulcers $(t=9.9 ; p<0.001)$.

Seromucoid levels in individual patients can be conveniently classified into three categories of low, normal, and high, according to an arbitrary normal range in our laboratory of 3 to $5 \mathrm{mg}$. SMT/100 ml. The seromucoid levels of our 50 patients with major haemorrhage are presented in this fashion in Table II, which shows that the underlying diseases-oesophageal varices, peptic ulceration, and carcinoma of the stomach-tend to be differentiated by low, normal, and high seromucoid levels respectively.

Our series of patients admitted with major haemorrhage consists mainly of peptic ulcer cases with relatively few examples of portal hypertension or carcinoma of stomach. We have therefore presented in Tables III and IV the seromucoid levels of a larger group of 114 patients suffering from these three diseases, but in whom major haemorrhage was not necessarily the presenting feature. (These 114 patients include the 50 presented in Tables I and II.) This 
TABLE I

SEROMUCOID LEVELS IN 50 PATIENTS WITH MAJOR UPPER GASTROINTESTINAL HAEMORRHAGE

\begin{tabular}{|c|c|c|c|c|}
\hline \multirow[t]{2}{*}{ Causal Condition } & \multirow[t]{2}{*}{ No. of Patients } & \multicolumn{3}{|c|}{ Seromucoid Level (mg. SMT/100 ml.) } \\
\hline & & Mean & Standard Deviation & Range \\
\hline $\begin{array}{l}\text { Oesophageal varices } \\
\text { Peptic ulceration } \\
\text { Carcinoma of stomach }\end{array}$ & $\begin{array}{r}5 \\
37 \\
8\end{array}$ & $\begin{array}{l}2 \cdot 43 \\
4 \cdot 39 \\
9 \cdot 41\end{array}$ & $\begin{array}{l} \pm 1 \cdot 26 \\
\pm 0.95 \\
\pm 2 \cdot 37\end{array}$ & $\begin{array}{l}1 \cdot 4-5 \cdot 3 \\
3 \cdot 1-7 \cdot 5 \\
6 \cdot 1-13 \cdot 0\end{array}$ \\
\hline
\end{tabular}

'Differ significantly from peptic ulcer group $(P<0.001)$.

TABLE II

DISTRIBUTION OF SEROMUCOID LEVELS IN 50 PATIENTS WITH MAJOR UPPER GASTROINTESTINAL HAEMORRHAGE Causal Condition Number of Patients with

\begin{tabular}{lll}
\hline Low Seromucoid Level & $\begin{array}{l}\text { Normal Seromucoid Level } \\
(0-3 \mathrm{mg} . S M T)\end{array}$ & $\begin{array}{l}\text { High Seromucoid Level } \\
(5+5 \mathrm{mg} . S M T)\end{array}$
\end{tabular}

Oesophageal varices Peptic ulceration

Carcinoma of stomach

$\begin{array}{lr}3 & 1 \\ 0 & 29 \\ 0 & 0\end{array}$

TABLE III

SEROMUCOID LEVELS IN 114 PATIENTS WITH PORTAL CIRRHOSIS, PEPTIC ULCERATION, OR

CARCINOMA OF STOMACH INCLUDING 50 PRESENTING WITH MAJOR HAEMORRHAGE

\begin{tabular}{|c|c|c|c|c|}
\hline \multirow[t]{2}{*}{ Condition } & \multirow[t]{2}{*}{ Number of Patients } & \multicolumn{3}{|c|}{ Seromucoid Level (mg. SMT/100 ml.) } \\
\hline & & Mean & Standard Deviation & Range \\
\hline $\begin{array}{l}\text { Portal cirrhosis }{ }^{1} \\
\text { Peptic ulceration } \\
\text { Carcinoma of stomach }{ }^{1}\end{array}$ & $\begin{array}{l}15 \\
56 \\
43\end{array}$ & $\begin{array}{l}2 \cdot 85 \\
4 \cdot 37 \\
8 \cdot 26\end{array}$ & $\begin{array}{l} \pm 1 \cdot 20 \\
\pm 1 \cdot 01 \\
\pm 2 \cdot 23\end{array}$ & $\begin{array}{l}1 \cdot 3-5 \cdot 3 \\
2 \cdot 9-7 \cdot 5 \\
2 \cdot 9-13 \cdot 7\end{array}$ \\
\hline
\end{tabular}

${ }^{1}$ Differ significantly from peptic ulcer group $(P<0.001)$.

TABLE IV

DISTRIBUTION OF SEROMUCOID LEVELS IN 114 PATIENTS WITH PORTAL CIRRHOSIS, PEPTIC ULCERATION, OR CARCINOMA OF STOMACH INCLUDING 50 PRESENTING WITH MAJOR HAEMORRHAGE

Condition

$$
\begin{aligned}
& \text { Number of Patients with } \\
& \hline \text { Low Seromucoid Level } \\
& (0.3 \mathrm{mg} . \text { SMT })
\end{aligned}
$$

Portal cirrhosis

Peptic ulceration

Carcinoma of stomach

larger series supports the contention that seromucoid levels differ significantly in patients suffering from cirrhosis, from peptic ulcer, and from gastric cancer (cirrhosis: peptic ulcer, $t=4.6 ; p<0.001$; peptic ulcer: carcinoma of stomach, $t=10.7, p<0.001$ ).

\section{DISCUSSION}

In his recent review of the diagnosis and management of upper gastrointestinal haemorrhage, Watkinson (1961) emphasizes the current interest in developing new methods of investigation designed to provide an early diagnosis of the causal condition. Early diagnosis is desirable in order that the appropriate treatment, particularly surgical intervention, can be speedily decided upon and confidently undertaken.

Early barium meals and early gastroscopy have never found general acceptance, because of a belief that the disturbance and manipulation involved might provoke further bleeding in an already dangerously ill patient. Continuous gastric suction with serial analysis of the aspirate (Chandler, Cameron, Nunn, and Street, 1960a) is without inherent risk; although certain secretory patterns 
can be related to the underlying pathology, the information provided is often inconclusive and reliance on this approach might involve dangerous delay in establishing the correct diagnosis. The most promising method of early investigation would appear to be the technique of immediate radiography of the stomach in the ward as described by Cantwell (1960) and by Chandler and his colleagues (1960 a, b). These authors have shown that a modified bariummeal examination without screening or palpation, conducted at the bedside with portable $x$-ray equipment during the acute phase of the bleeding, is safe and in their hands provides an overall diagnostic accuracy of about $80 \%$. The degree of accuracy obviously depends upon the availability and enthusiasm of an expert radiological team.

Seromucoid estimation can be performed in any hospital possessing a biochemistry laboratory, involves no more disturbance to the patient than a venepuncture, and provides a result within a few hours. If we take a low seromucoid level to indicate oesophageal varices, a normal level to indicate peptic ulcer, and a high value to indicate carcinoma, it can be seen from Table II that the test correctly indicated the source of the bleeding in $\mathbf{4 0}$ of our $\mathbf{5 0}$ patients, a diagnostic accuracy similar to that claimed for early bedside radiography.

When we come to compare the detailed results of immediate radiography as tabulated by Watkinson (1961) with our own findings, an interesting point emerges. Immediate radiography was found to have a high degree of accuracy in identifying peptic ulcers and oesophageal varices, but 'the diagnosis of carcinoma of the stomach presented the greatest diagnostic difficulty, being correctly diagnosed in only three of seven patients'. Seromucoid estimation has its lowest accuracy in distinguishing oesophageal varices from peptic ulcer and its highest accuracy in indicating cancer. It follows from this that the two methods of investigation are complementary and that their combined application should improve the accuracy of early diagnosis.

The diagnostic errors of seromucoid estimation in haematemesis can arise from several causes. Depression of seromucoid levels in cirrhosis reflects the degree of hepatocellular damage, and if this is still relatively slight and well-compensated, or if the portal hypertension is extrahepatic in origin, the seromucoid level will be found within the normal range. Raised seromucoid levels can arise from cancer or from any major acute inflammatory process (Cameron et al., 1961a). Thus the high seromucoid levels which we have recorded in some examples of haematemesis from benign peptic ulcer have usually occurred in patients with large penetrating gastric ulcers eroding the adjacent pancreas into an acute inflammatory mass. Similarly a patient who suffers a haematemesis from simple ulcer, during the course of any other acute inflammatory illness such as pneumonia, would be expected to have a high seromucoid level.

In cancer, the degree of seromucoid elevation depends upon the size and the grade of malignancy of the tumour, and in small early neoplasms of low malignancy normal values can be found; as tumour growth advances and ulceration occurs, the seromucoid level steadily rises (Cameron et al., 1961a). Thus, although some $12 \%$ of our total series of patients with stomach cancers had normal seromucoid levels (Table IV), all patients who presented with haemorrhage from ulcerating tumours had diagnostically high values.

From our experience in clinical practice, routine seromucoid estimation can be recommended as a valuable aid in the management of patients with haematemesis and melaena. In general the test is useful in giving an early indication of the causal disease in a high proportion of cases. In particular, knowledge of the seromucoid level can influence the difficult decision for or against 'emergency gastrectomy'. Thus, although a normal seromucoid level does not exclude oesophageal varices, an abnormally low level is strong evidence of their presence, and should act as a deterrent to hasty surgical intervention. On the other hand, a high seromucoid level should sway opinion towards early surgical exploration since, in our experience, this finding indicates that the source of bleeding is either carcinoma or a large, penetrating, acutely inflamed peptic ulcer of the type least likely to settle under conservative management. In our hands the routine application of the test has proved especially valuable in disclosing unsuspected stomach cancer. We have already encountered three patients with haematemesis with the combination of an 'acceptable ulcer history', a negative barium meal, and a high seromucoid level: in each, carcinoma of the stomach was demonstrated at subsequent laparotomy. Without seromucoid estimation these patients might very well have escaped detection. Clearly the finding of a high seromucoid level in any patient presenting with haematemesis and melaena requires an explanation and demands the fullest investigation.

In conclusion, we believe that the results of seromucoid estimation show sufficient correlation with the underlying disease to warrant its use as a routine diagnostic investigation in patients admitted with upper gastrointestinal haemorrhage.

We are indebted to our clinical colleagues in the Vale of Leven Hospital and in the Royal Alexandra Infirmary, Paisley, for permission to study patients under their care. 


\section{REFERENCES}

Cameron, E., Campbell, A., and Plenderleith, W. (1961a). Seromucoid in the diagnosis of cancer. Scot. med. J. , 6, 301-307. Ibid, 6, 308-310.

Cantwell, D. F. (1960). Ward barium meal examination in acute gastro-intestinal haemorrhage. Clin. Radiol., 11, 60-64.

Chandler, G. N., Cameron, A. D., Nunn, A. H., and Street, D. F. (1960a). Early investigations of haematemesis. Gut, 1, 6-13. $\frac{}{2,507-510},-(1960 \mathrm{~b})$. Haematemesis and melaena. Lancet,
Greenspan, E. M., Lehman, I., Graff, M. M., and Schoenbach, E. B. (1951). A comparative study of the serum glycoproteins in patients with parenchymatous hepatic disease or metastatic neoplasia. Cancer (Philad.), 4, 972-983.

Lockey, E., Anderson, A. J., and Maclagan, N. F. (1956). Urine and serum mucoproteins in cancer and other diseases. Brit. J. Cancer, 10, 209-221.

Watkinson, G. (1961). The diagnosis and management of upper gastro-intestinal bleeding. Practitioner, 186, 335-343.

Winzler, R. J., and Smyth, I. M. (1948). Studies on the mucoproteins of human plasma. II. Plasma mucoprotein levels in cancer patients. J. clin. Invest., 27, 617-619.

\section{The June 1962 Issue}

\section{THE JUNE 1962 ISSUE CONTAINS THE FOLLOWING PAPERS}

Selective surgery for peptic ulcer: a review IAN M. ORR

Peptic ulcer in hospital: An analysis of a 10\% in-patient enquiry throughout England and Wales H. DAINTREE JOHNSON

Ribonucleic acid and protein metabolism in the gut Part I Observations in gastro-intestinal cells with rapid turnover Part II Observations in the fixed secretory cells of the gut R. G. SHORTER and B. CREAMER

An experimental study of gastric cancer in relation to gastric ulcer R. STEIN-WERBLOWSKY

Pancreatic heterotopia as a cause of dyspepsia R. D. TONKIN, T. E. FIELD, and P. R. WYKES

Redundant colon as a cause of constipation PEKKA BRUMMER, PENTTI SEPPÄLÄ, and UNO WEGELIUS

Idiopathic steatorrhoea with intestinal pseudoobstruction H. A. MCCLELLAND, M. J. LEWIS, and J. M. NAISH

Subcutaneous fat necrosis, 'polyarthritis', and pancreatic disease P. F. LUCAS and T. K. OWEN
The blood volume and plasma protein levels before and after gastrectomy ALEXANDER SWAN, GEOFFREY T. ALLEN, and NORMAN C. TANNER

Gastric secretion in relation to subsequent duodenal ulcer and familial history J. H. BARON

The use of the colon as a substitute for the oesophagus P. J. CHRYSOSPATHIS and B. GOLEMATIS

Peripheral ligation of the hepatic artery during surgery in non-cirrhotic patients M. ANDREASSEN, J. LINDENBERG, and $\mathrm{K}$. WINKLER

Extracorporeal methods of reducing high blood ammonia levels H. D. RITCHIE, D. M. DAVIES, J. M. GODFREY, P. FAN, R. G. S. JOHNS, and J. PERRIN

The effect of anticholinergic drugs on the mucus content of gastric juice D. W. PIPER, MIRJAM C. STIEL, and BARBARA FENTON

\section{Methods and techniques}

Telemetering from within the body using a pressuresensitive radio pill B. W. WATSON, B. ROSS, and A. W. KAY

Measurement of gastrointestinal transit using radioactive chromium J. HANSKY and A. M. CONNELL

Copies are still available and may be obtained from the PUBLISHING MANAGER, BRITISH MEDICAL ASSOCIATION, TAVISTOCK SQUARE, w.c.1., price 17s. 6D. 